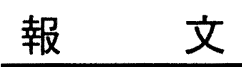

\title{
ヨウ素を增感剂としたリノール酸メチルの 光共役化反応
}

\author{
関桂・金子 良平・小林 克夫 \\ 宇都宮大学工学部応用化学科 (广 321 宇都宮市石井町 2753)
Photoconjugation of Methyl Linoleate in the Presence of Iodine as a Sensitizer

\author{
Katsura SeKI, Ryohei KANEKo, and Katsuo KobAYASHI \\ Department of Applied Chemistry, Faculty of \\ Engineering, Utsunomiya University \\ (2753, Ishii-cho, Utsunomiya-shi, $=321$ )
}

\begin{abstract}
The authors previously reported that polyunsaturated fatty acids having 1,4-diene structure can be easily conjugated at ordinary temperature using iodine as a photosensitizer.

This paper describes the optimum conditions for the iodine-sensitized conjugation of methyl linoleate under irradiation with a $100 \mathrm{~W}$ high-pressure mercury lamp and the mechanism involved.

A nonpolar solvent such as petroleum ether was used in this reaction. The optimum conditions of the reaction were as follows: approximately $0.1 \%$ of the amount of iodine added; $10 \%$ of the concentration of linoleate; room temperature; and irradiation for $1.5 \mathrm{~h}$ with a mercury lamp. Under these conditions, methyl linoleate was converted to conjugated dienoates in yields of approximately $80 \%$ along with small quantities of methyl trans-octadecenoates and polymers. No positional transfer selectivity of double bonds could be detected at all. The conjugated products were present in equal amounts as a mixture of methyl 9,11- and 10,12-octadecadienoates (the ratio of the cis, trans and trans, trans forms was $3: 7$ ).

It is considered that iodine atoms react only with the 1,4-diene system in this iodine-sensitized conjugation to first form a bridged iodoalkyl radical intermediate which is subsequently converted mainly into cis, trans conjugated forms accompanied by a shift of hydrogen and finally the geometrical isomerization equilibrium mentioned above is attained.
\end{abstract}

\section{1 緒 言}

リノール酸, リノレン酸などのポリエン化合物は 1,4 ージエン構造をもち, その共役異性化反応は古くから研 究されてきた。触媒としては水酸化アルカリ，ニッケル ・カーボン, ヨウ素及びその誘導体, カリウムアルコキ シド, 鉄ペンタカルボニルなど多くの報告 1) 3) があり, 二, 三のものは酵料用油の製造に, 脂肪酸組成の分析法 に利用された。しかしこれらの反応の多くはか(苛)酷な 条件を要する。著者らは前報4において, ヨウ素を光増 感剤とすればポリエン酸類は常温で容易に共役異性化す ることを見いだした。なおヨウ素を用いた光反応として
は共役ポリエン酸類のエライジン化 ${ }^{1), 5)}$ や，低温下での オレフィンからジョード化合物への誘導(列6) などがある が，位置異性化に用いた文献は見られない。

ここでは試料としてリノール酸メチルを用い, 水銀灯 照射下におけるこの増感共役化反応の最適条件を検討す ると共に, 反応生成物及び異性化機構について考察した ので報告する。

\section{2 実験}

\section{$2 \cdot 1$ 機器分析}

GC 及び熱分解 GC 測定は 20\% LAC-3 R-728/

Celite 60 80 mesh ( $\phi 4 \mathrm{~mm} \times 2 \mathrm{~m})$ のカラムを装着 
した YANAGIMOTO GCG 220 型ガスクロマトグラ フ ( TCD) を用いて, 主としてカラム温度 $215^{\circ} \mathrm{C}$ で行っ た。ここでの熱分解 GC とは, 上記条件下でオゾニド 溶液を直接 GC に導入し，オゾニドを注入口で開裂さ せ，生成するアルデヒド類をそのまま分析する方法であ る。

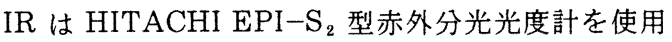
し，液膜法または $\mathrm{KBr}$ 錠剤法で測定した。

UV は Beckman DU 型分光光度計で, ヘプタン溶液 として測定した。

\section{$2 \cdot 2$ リノール酸メチルの製取}

サフラワー油脂肪酸メチルを尿素付加分別法により処 理し，その母液部を精留してリノール酸メチルを得た。 bp $180 \sim 188^{\circ} \mathrm{C} / 6 \mathrm{~mm} \mathrm{Hg}, n_{\mathrm{D}}^{20} 1.4617$, けん化価 190.4 , ヨウ素価 171.8 , 純度 $99.3 \%$ 。

\section{$2 \cdot 3$ リノール酸メチルのヨウ素增感異性化}

反応には $100 \mathrm{~W}$ 内部照射型高圧水銀灯装置（ウシオ 電機製 UM-102 型, パイレックスフィルター, 容量 $300 \mathrm{~mL}$ ) を使用した。

まずヨウ素溶液をつくり，これにリノール酸メチルを 加えて試料溶液 ( wt $/ \mathrm{vol}) 300 \mathrm{~mL}$ を調製し, 窒素導入 下, 增感異性化を行った。定期的に $5 \mathrm{~mL}$ の反応液を 採り, 常法によりチ才硫酸ナトリウム処理して反応生成 物とした。その $n_{\mathrm{D}}, \mathrm{TLC}, \mathrm{UV}, \mathrm{GC}, \mathrm{IR}$ などを測定し て反応追跡すると共に, UVから共役オクタデカジエン 酸メチル (以下共役ジエンと略記) 含量 ${ }^{7)}$ を算出した。

なお反応溶媒はそれぞれ所定の精製を行い, 石油エ一 テルは $\mathrm{bp} 40 \sim 60^{\circ} \mathrm{C}$ の留分を使用した。

反応温度は Fig. -5 及び Fig. -7 を除き, すべて $25^{\circ} \mathrm{C}$ である。

$2 \cdot 4$ cis, trans-及ひ trans, trans-共役ジェン酸の 分画

反応生成物（共役ジエン $79 \%, 20 \mathrm{~g}$ ）を加水分解して 脂肪酸とした。これから再結晶及び尿素付加分別法を併 用して, cis, trans-共役ジエン酸 $(92 \%, 1.6 \mathrm{~g})$ 及び trans, trans-共役ジエン酸 $\left(\mathrm{mp} 47.5 \sim 48.5^{\circ} \mathrm{C}, 95 \%\right.$, $8.2 \mathrm{~g})$ とに分画した。

\section{$2 \cdot 5$ trans, trans-共役ジェンの幾何異性化}

trans, trans-共役ジエン $10 \%, \exists ウ$ 素 $0.05 \sim 1 \%$ の 石油エーテル溶液を調製（内部標準としてパルミチン酸 メチル 0.1 モル当量を含有）し, $2 \cdot 3$ の水銀灯照射装置 を用いて異性化反応を行った。反応生成物の分析はUV, GC 及び IRにより行った。

\section{$2 \cdot 6$ 反応生成物のオゾン分解}

$2 \cdot 3$ の反応生成物及び $2 \cdot 4$ の共役ジエンそれぞれ 1 $\mathrm{g}$ をクロロホルム $10 \mathrm{~mL}$ に溶解し， $-20^{\circ} \mathrm{C}$ でオゾン化 した。前者はそのまま熱分解 GCにより分析した。ま た後者は減圧下で溶媒を留去し, 酸化分解してカルボン
酸を得た後、メチルエステルとし GC 分析を行った。

\section{3 結果亡考察}

\section{$3 \cdot 1 \quad \exists$ 素增感共役化の最適条件}

ヨウ素は, 溶媒の違いにより 3 種の色相 $(\mathrm{a} \sim \mathrm{c})$ を呈 する。a）紫色溶液：石油エーテル, ヘキサン, 四塩化 炭素, クロロホルム, 二硫化炭素なざ b) 赤紫色溶液 : ベンゼン, トルエンなどの芳香族炭化水素 $\mathrm{c}$ ) 褐色溶 液: 水, アルコール, アセトン, エーテル, アミン類。

これら溶液の色相は温度によって变わる場合がある。 例えば紫色の二硫化炭素溶液をドライアイスの温度に冷 却すると褐色になり, 褐色溶液は一般に加温すると紫色 になり冷やすと元に戻る。紫色溶液ではヨウ素蒸気と良 く類似した吸収スペクトルを示し、ヨウ素は分子状で存 在する。赤紫色溶液中ではベンゼンなどと $\pi-\sigma$ 型の弱 い電荷移動錯体を形成し，また褐色溶液ではそれより安 定な錯体として存在するためと説明されている ${ }^{8)}$ 。

そこで,この共役化の最適条件を検討するのに先立ち, まず上記 3 種の色相を呈する代表的な石油エーテル, ベ ンゼン及びエ夕ノール溶液に, 試料のリノール酸メチル を添加し，その電子スペクトルを測定した (Fig.-1)。 石油エーテル溶液の場合, 紫色から赤紫色を呈した。こ れはヨウ素が試料の二重結合と $\pi-\sigma$ 型の弱い結合を形 成するためであり，スペクトル的にも可視領域でのブ ルーシフトが観察された。エタノールや $\lambda_{\max } 298 \mathrm{~nm}$ に電荷移動吸収帯を示すベンゼン溶液の場合には, 試料

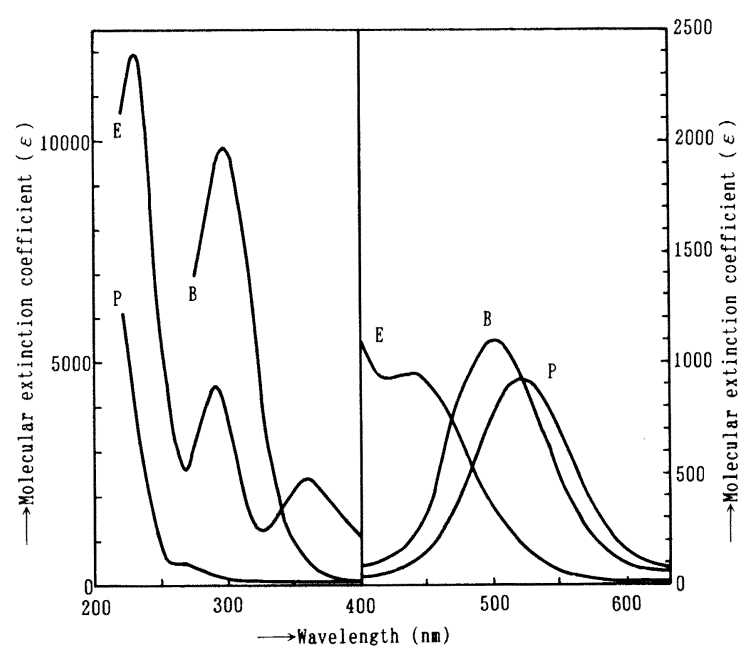

$$
\begin{array}{ll}
\text { Pat concentration: } & 0.40 \mathrm{nM} \\
\text { Iodine concentration: } & 0.11 \mathrm{mM} \\
\text { Solvent: } &
\end{array}
$$

P: Petroleun ether, B: Benzene, E: Ethanol

Fig. -1 Electronic spectra of various solutions containing iodine and methyl linoleate. 


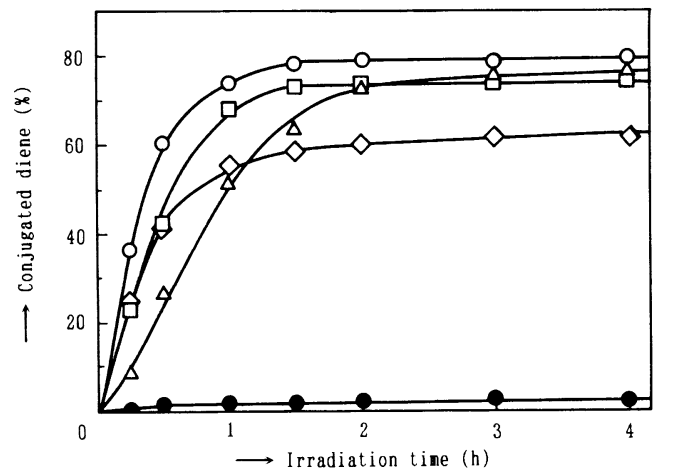

Pat concentration: $\quad 10 \%$ lodine concentration: $\quad 0.1 \%$ Solvent:

- - Petroleum ether, $-\Delta-$ Carbon tetrachloride, $-\square-$ Benzene, $-\diamond-$ Carbon disulfide, - - Acetone, Ethanol

Fig.-2 Effect of solvent on photoconjugation process of methyl linoleate with iodine-sensitizer at $25^{\circ} \mathrm{C}$.

添加の影響は特に認められなかった。

これらの点を考慮して, 次にこの共役化反応に及ぼす 溶媒の影響を調べたFig. - 2 に示した様に, 試料 10\%, 增感剤 $0.1 \%$ の溶液では, 石油エーテルの場合が最も速 やかに反応し, $1.5 \mathrm{~h}$ で共役ジエンが約 $80 \%$ の平衡に達 した。ベンゼン, 四塩化炭素となるに従い反応が遅くな り, 平衡に達するのにそれぞれ約 $1.5 \mathrm{~h}, 3 \mathrm{~h}$ を要した。 $\lambda \max 318 \mathrm{~nm}$ に吸収を有する二硫化炭素では, $2 \mathrm{~h}$ で平 衡になったが，共役ジエン量は $60 \%$ にとどまった。ま たアセトン及びエ夕ノールではほとんど反応せず, これ はヨウ素が溶媒之光化学反応を起こすためか, あるいは 液体格子貫入錯体 ${ }^{9}$ を形成し安定化するためと考えられ る。

この增感反応では, 試料溶液として $500 \mathrm{~nm}$ 付近に吸 収極大を示し, しかもパイレックスフィルター条件下で の紫外領域にそれ自身が吸収を持たない溶媒, とりわけ 炭化水素系のものが良い結果を与えた。

そこで,リノール酸メチルの $10 \%$ 石油エーテル溶液 に, $0.01 \sim 0.3 \%$ のヨウ素を添加してその影響を調べた。 Fig.-3 の様に, ヨウ素濃度の低い範囲では共役ジェン 生成量は添加量の増加に伴って急速に増大し， $0.1 \% の$ 場合ほぼ最大平衡（約 80\%）に達した。さらに高濃度に なると生成量の減少が見られ, 不溶性重合物及び微量の モノエンの副生も認められた。なおヨウ素熱異性化の際 には著量の transーオクタデセン酸メチルが生成するよ の報告 ${ }^{10)}$ 見られる。

次にヨウ素量 $0.1 \%$ における試料濃度の検討を行った (Fig. -4)。低濃度, すなわち試料に対する増感剂の比
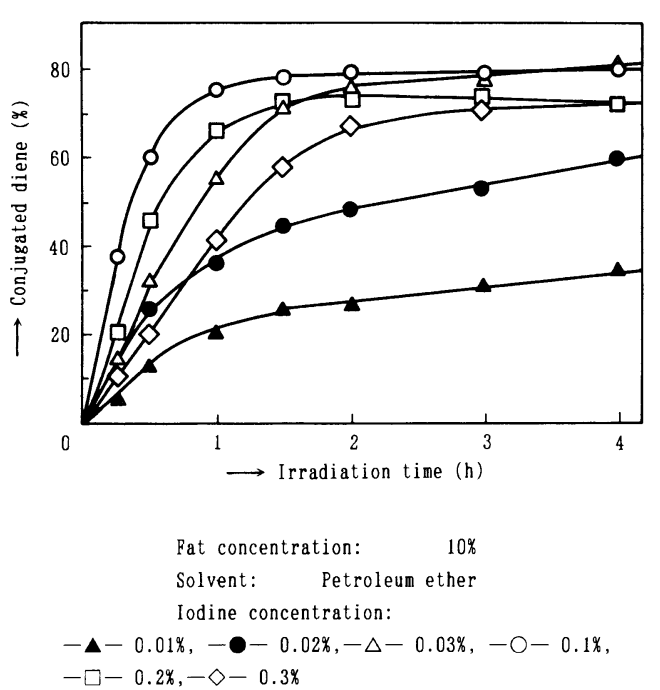

Fig. -3 Effect of iodine concentration on photoconjugation process of methyl linoleate with iodine-sensitizer at $25^{\circ} \mathrm{C}$.
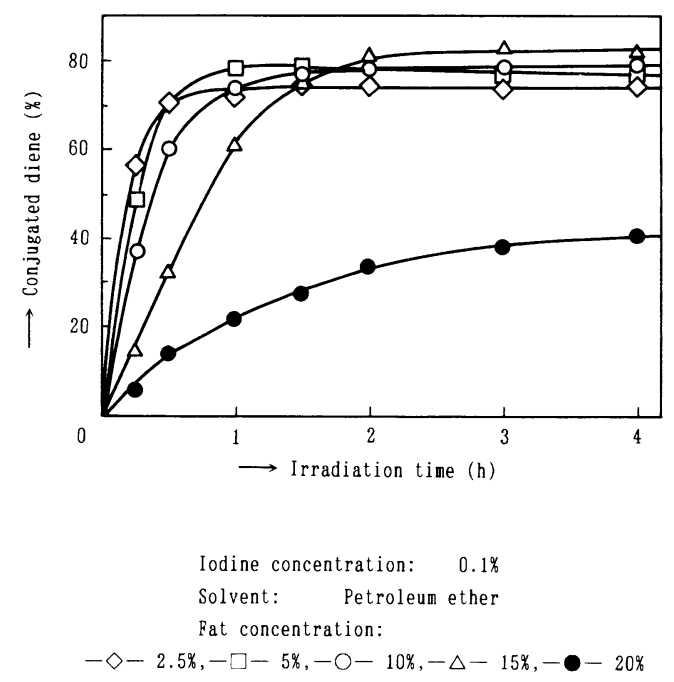

Fig. -4 Effect of fat concentration on photoconjugation process of methyl linoleate with iodine-sensitizer at $25^{\circ} \mathrm{C}$.

率が大きい場合には反応は速やかに進行するものの, 重 合のため共役ジエン生成量はわずかながら低下した。 5 $\%, 10 \%$ の場合は 1 1.5 h で平衡になり, 15\%では平 衡に達するのに $3 \mathrm{~h}$ を要したが, 反応が温和になるため 最終的に生成する共役ジエン量は $82 \%$ であった。リ ノール酸メチル $20 \%$ では明らかに増感剂不足のため, 反応は非常に遅くなった。

先に触れた样に, この反応においては試料溶液の色相, すなわちヨウ素の溶存状態が重要であり,これは温度に 


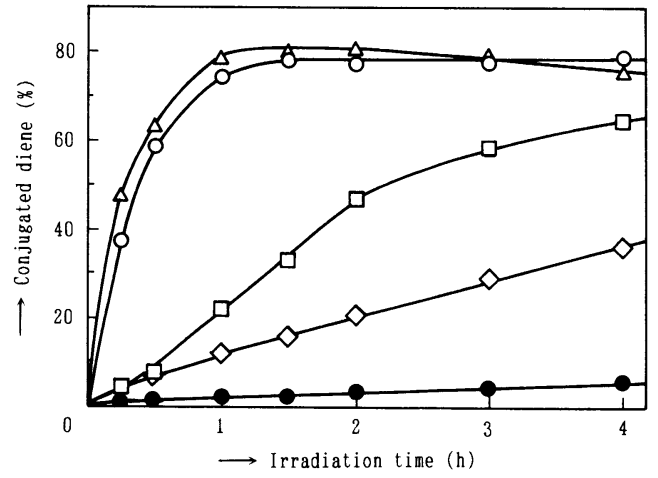

Fat concentration: $\quad 10 \%$ Iodine concentration: $\quad 0.1 \%$ Solvent: Petroleum ether Temperature:

$-25^{\circ} \mathrm{C},-\diamond-0^{\circ} \mathrm{C},-\square-4{ }^{\circ} \mathrm{C},-\mathrm{O}-25^{\circ} \mathrm{C},-\triangle-40^{\circ} \mathrm{C}$

Fig. -5 Effect of temperature on photoconjugation process of methyl linoleate with iodinesensitizer.

よっても異なる。これまでの実験はすべて反応を $25^{\circ} \mathrm{C}$ で行ったので, 次に温度の影響を調べた。Fig.-5に示 した様に, 二ヨウ化物が安定に存在し得る $-25^{\circ} \mathrm{C}$ では, 共役異性化はほとんよ゙進まなかった。やはり温度の上昇 に伴って共役ジェン生成量の増加が見られ, $25^{\circ} \mathrm{C}, 40^{\circ} \mathrm{C}$ で最大になった。しかし $40^{\circ} \mathrm{C}$ では不溶性重合物の生成 も認められた。

先の Fig.-2 に示した様に, 反応は緩やかであるが比 較的好結果を与えた四塩化炭素につき, ヨウ素添加量の 影響 (Fig.-6) 及び反応温度の効果 (Fig.-7) を調べ た。この溶媒でも增感剤 $0.1 \%$, 試料濃度 $10 \%$ 程度が良 好であり，また反応温度 $50^{\circ} \mathrm{C}$ では $50 \mathrm{~min}$ で共役ジエ ン量は最高（約 $80 \%$ ) になるが, その後は重合のため減 少する傾向を示した。

以上のことからヨウ素増感異性化反応は, 溶媒として 石油エーテルやへキサンなどを用い， ヨウ素添加量約 $0.1 \%$,リノール酸メチル濃度約 $10 \%$, 常温で光照射する のが最適と考えられる。

\section{$3 \cdot 2$ 反応生成物の検討}

反応生成物は IR において, $988 \mathrm{~cm}^{-1}$ にtrans, trans 一共役ジエンによる強い吸収と cis, trans-共役ジエン による弱い $948 \mathrm{~cm}^{-1}$ の吸収帯が現れ，また $965 \mathrm{~cm}^{-1}$ にトランス孤立二重結合によるショルダーも見られた。 なお GCによれば cis, trans一及び trans, trans一共役 ジエンの比率は大体 $3: 7$ であり, cis, trans-共役ジエ ンのヨウ素増感幾何異性化の結果 ${ }^{5)}$ と一致した。

また本実験で分画したtrans, trans-共役ジエンの石 油エーテル溶液における幾何異性化を行った。これによ

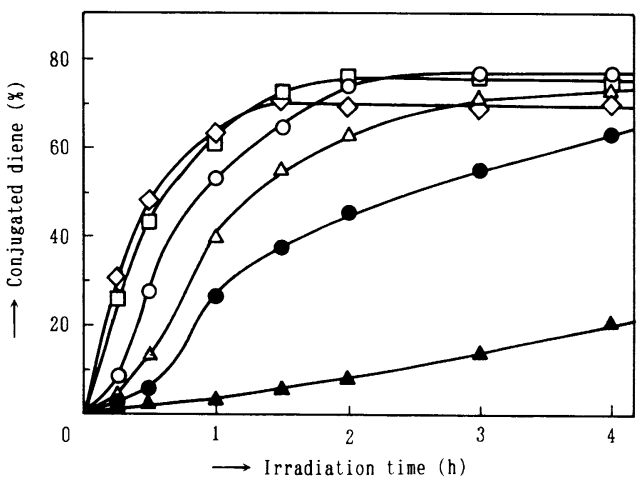

Fat concentration: $\quad 10 \%$ Solvent: Carbon tetrachloride Iodine concentration:

$-\boldsymbol{\Delta}-0.01 \%,-0.02 \%,-\triangle-0.03 \%,-\mathrm{O}-0.1 \%$,

$-\square-0.2 \%,-\diamond-0.3 \%$

Fig.-6 Effect of iodine concentration on photoconjugation process of methyl linoleate with iodine-sensitizer at $25^{\circ} \mathrm{C}$.

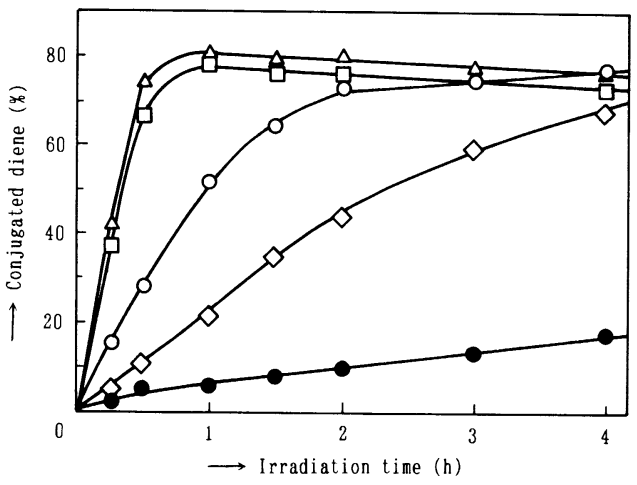

Fat concentration: $\quad 10 \%$

Iodine concentration: $\quad 0.1 \%$

Solvent: Carbon tetrachloride

Temperature:

$-15^{\circ} \mathrm{C},-\diamond-0^{\circ} \mathrm{C},-\mathrm{O}-30^{\circ} \mathrm{C},-\triangle-50^{\circ} \mathrm{C},-\square-65^{\circ} \mathrm{C}$

Fig.-7 Effect of temperature on photoconjugation process of methyl linoleate with iodinesensitizer.

るとヨウ素濃度 0.05 0.25\% の範囲では濃度に関係な く異性化平衡 (cis, trans一及び trans, trans一共役ジエ ン生成比 約 $3: 7)$ に達し，ほとんど副反応が恐められ なかった。しかし $0.75 \%$ 以上之高濃度になるに従い不 均化反応が顕著之なり, trans-モノエン酸メチルと重 合物の副生も增大した。ヨウ素量 $0.05 \%$ の結果を Fig. -8 に示した。

次に共役異性化に際し, 二重結合の移動に特異性があ 

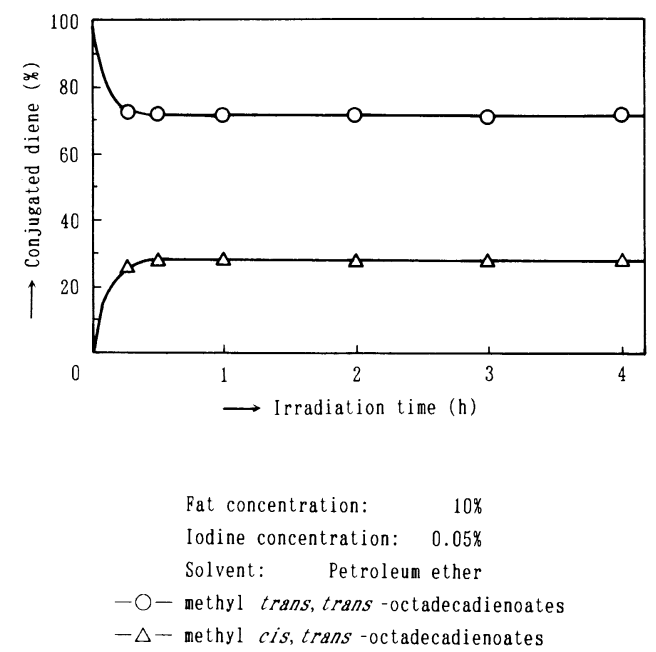

Fig.-8 Photoisomerization process of methyl conjugated trans,trans-octadecadienoates with iodine-sensitizer at $25^{\circ} \mathrm{C}$.

るかどうか調べた。2・3 の反応生成物のオゾニドを熱分 解 GC で分析したところ，9，11-及び 10，12-共役ジエ ンに対応するへプタナールとへキサナールが，また 9オキソノナン酸メチルと10-オキソデカン酸メチルがそ れぞれ 1:1の割合で検出された。一方反応物から分画 した cis, trans-及び trans, trans-共役ジエンのオゾ ン分解においても，いずれもへキサン酸，ヘプタン酸， アゼライン酸及びセバシン酸のメチルエステルを与え た。またアゼライン酸とセバシン酸の生成比はやはり両 者とも1：1であった。これらの事実から，この共役化 反応においても位置移動選択性は全く認められず，9， 11一及び 10,12-異性体の等量混合物であった。

以上のことから，この共役化ではそれぞれ cis-9, trans-11-; trans-9, cis-11-; cis-10, trans-12-; trans-10, cis-12- 並びに trans-9, trans-11-; trans-10, trans-12-共役ジエンが約 $3: 7$ の比で生成 したことになる。

\section{3 ヨウ素增感異性化の反応機構}

反応機構を考えるにあたって, この反応の特徵的な事 項を下記に示した。

1） 1,4-ジエン構造のリノール酸メチルとヨウ素を 含む試料溶液（赤紫色）に, 光照射すると速やかに退色 が起こり，これを暗所に戻すと元の溶液の色相に回復す る。なお，この段階では異性化は起こっていない。さら に照射を続ける之褐色を呈して反応が始まり，この段階 ではもはや光を遮断しても元の色相に戻らない。この反 応では最終的に $80 \%$ 程度の共役ジエン (cis, trans 及 びtrans, trans の比 $3: 7)$ を生成した。

2）オレイン酸メチルの場合には, この様な色相の変
化は見られず，エライジン化も全く認められなかった。

3）この増感反応は白色蛍光灯照射下でも速やかに進 行する。なお白色蛍光灯は八ロリン酸カルシウムを蛍光 体としており，600 nm を中心波長とした可視光線を放 出する。

4）1）と同様な溶液を暗所で $4 \mathrm{~h}$ 還流，あるいは暗 所に一夜放置した場合, 共役ジエン生成量はいず扑 ずか 1 2\%にとどまった。

5） 反応溶液を活性アルミナに通すと無色になるが, 散乱光でも微量のヨウ素を再遊離して淡赤紫色を呈し た。

以上の事実を考虑して,反応機構を次の様に考察した。 この増感共役化が蛍光灯照射でも進行する点や, Fig.1 の石油エーテルあるいはベンゼン溶液の電子スペクト ルなどから, 高圧水銀灯の場合には可視波長, 特に 436, 546 及び $577 \sim 579 \mathrm{~nm}$ の光が反応に関与したもの と考えられる。

従ってこの反応では, まず可視光線によるヨウ素分子 の解離が起こり, 次にヨウ素原子がリノール酸メチルの 二重結合へ付加し, 橋かけ構造のヨードアルキルラジカ ルを形成する。ここで水素移動を起こして,より安定な 共役ラジカルに移行する。次に, これからヨウ素原子が 脱離する際, 幾何異性化を伴ってシス, トランスを主体 とする共役ジエンへ変換する。このものはさらにヨウ素 増感幾何異性化により, 最終的に cis, trans一及び trans, trans-共役ジエンの平衡に達する。なお先に述 べた様に 1，4-ジエンとモノエンとでは反応性に明らか な違い 1)，2）がある。1，4-ジエン系においては，中間 体ヨードアルキルラジカルのヨウ素が隣接する二重結合

$$
\mathrm{I}_{2} \stackrel{h \nu}{\rightleftarrows} 2 \mathrm{I} \cdot
$$<smiles>c1ccccc1</smiles><smiles>CC=CC=CCC</smiles><smiles>C=CC1=CC=CC2=CC=CC=CC12</smiles><smiles>C=C/C=C\C=C/C</smiles><smiles>C/C=C\C=C\C=C\C(=C/C)\C=C\C</smiles>

Fig.-9 Conjugation mechanism of methyl linoleate in the presence of iodine as a sensitizer. 
と $\pi$ 錯体を形成してそれ自体安定化し，ラジカル生成を 容易にするものと考えられる。幾何異性化の際にも共役 ジエンはヨウ素原子と $\pi$ ーアリル型の錯体を形成し得る のに対し，モノエンでは形成されずエライジン化も進行 しないものと推測される。

また先に述べた様に，照射開始と共に反応溶液の退色 が認められたことは, 反応初期にヨウ素分子の橋かけ ヨードアルキルラジカルへのトランス付加が起こり, 無 色の二ヨウ化物の生成を予想させるものである。しかし この化合物は常温では不安定 ${ }^{6)}$ であり, 異性化の進行に 伴いFig. -9 に示した様な経路で徐々に消失し，最終的 にはほとんら゙残っていなかった。さらに共役異性化の進 行に伴い, 還元された transーオクタデセン酸メチルや, またTLCによるとダイマーなどの重合物の存在も少量 認められた。この様な共役ジエン経由の不均化反応も多 少起こっている様である。

この反応機構については，今後中間体や生成物などの 観点から詳細に検討する予定である。

[平成元年 (1989) 5 月 12 日受理]

文献

1）不飽和脂肪酸異性化の総説は, H.J. Harwood,
Chem. Rev., 62, 134 (1962); 橋本哲太郎, 化工資, 30, 182 (1962);D. Swern, “Baily's Industrial Oil and Fat Products", 4 th Ed., Vol.1, John Wiley \& Sons, New York (1979), p. 159

2) J. Ugelstadt, B.J. Jenssen, P.C. Mörk, Acta Chem. Scand., 16, 323 (1962); 高木 徹, 福住一雄, 南谷晴子, 油化学, 18, 193 (1969)

3）橋本哲太郎, 椎名久子, 油化学, 9, 79 (1960); 椎名久 子, 橋本哲太郎, 油化学, 24, 161 (1975)

4）金子良平, 関 桂, 小宮山勝志, 近喰秀男, 日化, 91, 1193 (1970)

5) J.R. Chipault, J.M. Hawkins, J. Am. Oil Chem. Soc., 37, 176 (1960)

6) P.S. Skell, R.R. Pavlis, J. Am. Chem. Soc., 86, 2956 (1964); A. Schönberg, "Preparative Organic Photochemistry", Springer-Verlag, Berlin (1968), p. 353

7）日本油化学協会編, “基準油脂分析試験法”, (1971) 2. 4.15-71

8) J. Kleinberg, A.D. Davidson, Chem. Rev., 42, 601 (1948); 長倉三郎, “有機電子理論”, 培風館 (1966), p. 186;早川久雄, 化学教育, 18, 230 (1970)

9) P.A.D. de Maine, J. Chem. Phys., 26, 1192, 1199 (1957)

10）窪田安彦, 橋本哲太郎, 油化学, 23, 301 (1974); 油化 学, 25, 393 (1976)

\section{国際油脂情報}

[Cocomunity 15 Oct. 1989 吉富和彦]

Łマレーシア，ココナッツ製品の輸出増加へ

マレーシア 1 次産業省の予備統計によれば, マレーシアのココナッツ製品の輸出は 1989/90 年度に増加する見 込みである。ココナッツ製品にはフレッシュ・ナッツ，乾燥ココナッツ及び精製ココナッツ油が含まれる。この うち乾燥ココナッツは 1988 年の $32,625 \mathrm{t}$ から 1989 年には $35,000 \mathrm{t}$ へと最も大きく伸び, 次いでフレッシュ・ ナッツが 4,560 万個から 4,600 万個に増大し，精製ココナッツ油も 1 万 7,900 t から 1 万 $8,000 \mathrm{t}$ へと増加する。 1990年の主要ココナッツ製品輸出目標は次のようである。フレッシュ・ココナッッ4 800 万個, 乾燥ココナッッ 3 万 $8,000 \mathrm{t}$, ココナッツ原油 3 万 $6,000 \mathrm{t}$, 精製ココナッツ油 2 万 $\mathrm{t}$ 。マレーシアのココナッツ製品輸出市場はア メリカ, シンガポール, ホンコン, バングラデシュ, 西ドイツ, オランダ及びカナダである。

\section{$\star \mathrm{UCAP} / \mathrm{PCRDF}$ のアフラトキシンを含まないコプラに関するセミナー}

フィリピン連合ココナッツ協会 (UCAP) とフィリピン・ココナッツ研究開発財団 (PCRDF) は, 共催でミ ンダナオにおいてアフラトキシンを含まないコプラ生産に関するセミナーを開催した。本セミナーはコプラ生産 工程における適正な乾燥技術の重要性と，アフラトキシン污染の原因となる力ビの生成を止める化学薬品の使用 に焦点が置かれた。本セミナーは不適当な天日乾燥法がしばしば実施されているミンダナオ島のコタバト及びダ バオにおいてアフラトキシン含量がもっとも高いので，ミンダナオにおいて開催されたと PCA はいう。

\section{ネインド，油糧種子増産のための共同体を推進}

インドのカルカッタで行われた油糧種子と農業技術に関する最近のセミナーでは, 研究開発を押し進めること により，油糧種子の開発推進のための共同体を採用するよう食用油製油工業界に呼びかけを行った。

この目的のため，各地の製油企業は個々もしくはグループを組んでいくつかの共同体を結成し，地域的に搾油 される油糧種子の生産と生産性の増大を図るよう要請された。製油企業は, 特定生産者により全油糧種子が購入 されることになるという理解のもと, 高収率の油糧種子の品種を適当な時期に適当量, 補助金付き料金で調達で きる見込みである。 